OPEN ACCESS

Edited by:

Ciro Rico,

University of the South Pacific, Fiji

Reviewed by:

Duan Delin,

Institute of Oceanology (CAS), China

Kiyotaka Nagaki,

Okayama University, Japan

${ }^{*}$ Correspondence:

Zhi-Gang Zhou

zgzhou@shou.edu.cn

tThese authors have contributed equally to this work

Specialty section:

This article was submitted to Marine Molecular Biology

and Ecology,

a section of the journal

Frontiers in Marine Science

Received: 03 March 2020

Accepted: 27 August 2020

Published: 25 September 2020

Citation:

Dong W-S, LiU P-F, LiU Y, Du Y,

Bi Y-H and Zhou Z-G (2020)

Immunocytochemical Localization of the Kinetochore Protein Nuf2p on the Gametophyte Chromosomes of a

Cultivar of Saccharina (Phaeophyta).

Front. Mar. Sci. 7:539260.

doi: 10.3389/fmars.2020.539260

\section{Immunocytochemical Localization of the Kinetochore Protein Nuf2p on the Gametophyte Chromosomes of a Cultivar of Saccharina (Phaeophyta)}

\author{
Wu-Shan Dong ${ }^{1 \dagger}$, Peng-Fei Liu' ${ }^{1 \dagger}$, Yu Liu' ${ }^{1}, Y u$ Du ${ }^{1}$, Yan-Hui Bi ${ }^{1,2}$ and Zhi-Gang Zhou ${ }^{3 *}$ \\ ${ }^{1}$ Key Laboratory of Exploration and Utilization of Aquatic Genetic Resources, Ministry of Education, Shanghai Ocean \\ University, Shanghai, China, ${ }^{2}$ National Demonstration Center for the Experimental Teaching of Fisheries Science, Shanghai \\ Ocean University, Shanghai, China, ${ }^{3}$ International Research Center for Marine Biosciences, Ministry of Science \\ and Technology, Shanghai Ocean University, Shanghai, China
}

Nuclear filament-containing protein 2 (Nuf2p), a centromere-associated protein, is an indispensable component of Ndc80 complex, which is important for stable microtubulekinetochore attachment, chromosome pairing, and spindle assembly in mitosis. Based upon contig sequences coding for Nuf2p from a pyrosequencing transcriptome of Saccharina japonica, primers were designed for molecular cloning of this kinetochore protein. The open reading frame (ORF) of this gene SjNuf2 was 1,452 bp long, encoding a putative protein consisting of 483 amino acids. Multi-sequence alignment showed SjNuf2p possessed several conserved domains of Nuf2, Spc7, SPT2, and MIT. To illustrate the location of SjNuf2p using immunocytochemistry, its ORF was inserted into a prokaryotic expression vector pET-28a. Then, the recombinant SjNuf2p (rSjNuf2p) was induced to be expressed in Escherichia coli. The rSjNuf2p was verified by Western blotting with the commercial anti- $6 \times$ His-tag antibody and then purified using affinity chromatography. The polyclonal antibody of anti-SjNuf2p was raised against the purified rSjNuf2p. Western blotting with this prepared antibody showed the presence of SjNuf2p in the gametophytes of a Saccharina cultivar. SjNuf2 $p$ and $\alpha / \beta$-tubulin were subsequently co-localized to the paraffin sections of kelp chromosomes with their corresponding antibodies, thus illustrating that SjNuf2p could reside at the kelp centromeres. This study laid a solid foundation for kelp centromere and karyotype analyses.

Keywords: centromere, immunolocalization, kinetochore, microtubule, Nuf2, Saccharina japonica

\section{INTRODUCTION}

Chromosomes of Saccharina japonica (Aresch.) C. E. Lane, C. Mayes, Druehl et G. W. Saunders (=Laminaria japonica Aresch.) are numerous in number and small in size (Evans, 1963; Yabu and Yasui, 1991; Lewis, 1996). Their features, short rod-like or even dot-like shaped, prevent the karyotype analysis using routine cytological methods only. However, after the enzymatic treatment for kelp chromosome preparation and the staining with 4',6-diamidino-2-phenylindole (DAPI), Liu et al. (2012) successfully localized a female-specific marker on one of the kelp gametophyte 
chromosomes by use of fluorescence in situ hybridization (FISH). Using such a protocol, Liu et al. (2017) illustrated the location of ribosomal RNA (rRNA) genes on kelp chromosomes, and Yang et al. (2017) provided the first cytogenetical evidence that the telomere of S. japonica chromosomes was Arabidopsistype. For lack of available centromeric DNA sequences so far, there is no report on the precise localization of chromosomal centromeres and subsequent karyotype analysis of $S$. japonica using FISH technique.

Centromere, appearing at the constricted regions of mitotic chromosomes, is a functional locus and responsible for chromatid cohesion and segregation in mitosis (Przewloka and Glover, 2009; Oliveira and Torres, 2018). Just at the centromere, kinetochore, linking centromeric DNA to spindle microtubules, is constituted by a number of conserved protein complexes to form a proteinaceous structure (Westermann et al., 2007; Cheeseman and Desai, 2008). Of these complexes, Ndc80 complex is a long, dumbbell-shaped hetero-tetramer built mainly from the four proteins Nuf2p (nuclear filament-containing protein 2), Heclp (highly expressed in cancer 1) or Ndc80p (nuclear division cycle 80), Spc24p (spindle pole body component 24 ), and Spc25p in both yeast Saccharomyces cerevisiae and humans Homo sapiens (Liu et al., 2007; Ciferri et al., 2007; Westermann et al., 2007; Santaguida and Musacchio, 2009), thus showing its conservation. The carboxyl termini of Spc24p and Spc25p anchor the Ndc80 complex into the kinetochore, whereas amino-terminal domains of Nuf2p and Hec1p reside exterior to Spc24 and Spc25, poised to interact with the plus ends of spindle microtubules (Sundin et al., 2011). It is therefore suggested that Nuf2p, product of the gene Nuf2, played an important role in the attachment of microtubules to the centromeres of chromosomes by directly binding microtubules for spindle assembly and chromosome alignment at metaphase.

Nuf2 was first discovered in S. cerevisiae, and its product was identified to be a protein associated with the spindle pole body (Osborne et al., 1994). To date, a few reports were focused on Nuf2 mainly in budding yeast S. cerevisiae (Osborne et al., 1994; Wigge and Kilmartin, 2001), fission yeast Schizosaccharomyces pombe (Nabetani et al., 2001; Asakawa et al., 2005), and humans H. sapiens (DeLuca et al., 2002; Liu et al., 2007). Nuf2 is rarely investigated in plants and has only been reported in Arabidopsis thaliana (Ramahi, 2012; Shin et al., 2018). By fusion expression of green fluorescent protein in Arabidopsis, Shin et al. (2018) observed that this gene product Nuf2p (GenBank accession No. AEE33765) was co-localized with the Ndc80 complex at the outer kinetochore for the binding to the acidic tails of the $\alpha$ and $\beta$-tubulin dimers in microtubules. Taken together, these reports demonstrated that Nuf2 was conserved between point and regional centromeres (Joglekar et al., 2008) and even in the examined organisms as suggested by Wigge and Kilmartin (2001). Accordingly, we suspected that such a key protein at the kinetochore-microtubule interface might also be conserved in other organisms such as a cultivar of Saccharina.

In general, connecting microtubules to chromosomes via kinetochores occurred only at the centromeres in cell division. This fact reminded that we can use immunocytochemistry to functionally identify the gene SjNuf2 by co-localizing SjNuf2p with microtubules on the kelp chromosomes. With this in mind, following molecular cloning of SjNuf2 from the cultivar of Saccharina with the designed primers based on its contig coding sequence from a pyrosequencing transcriptome of this kelp (Ye et al., 2015), it was heterologously expressed in Escherichia coli. Against the isolated and then purified recombinant SjNuf2p (rSjNuf2p), anti-SjNuf2 polyclonal antibody was generated. Using the purified anti-SjNuf2 antibody, the site of SjNuf2p on the kelp chromosomes was illustrated by immunocytochemically co-localizing with commercial $\alpha / \beta$-tubulin antibody. To our knowledge, this is the first report on algal Nuf2 protein, and the present study will lay a solid foundation for obtaining centromeric DNA and subsequently analyzing karyotype of this kelp by use of FISH.

\section{MATERIALS AND METHODS}

\section{Algal Strain and Culture}

The Rongfu strain, a hybrid cultivar between S. japonica and Saccharina longissima, was selected as the algal materials in the present study. Its gametophyte clones germinated from zoospores were isolated under a microscope and cultured in 500-ml flasks under vegetative growth conditions of $30 \mu \mathrm{mol}$ photons $\mathrm{m}^{-2} \mathrm{~s}^{-1}$ at $17 \pm 1{ }^{\circ} \mathrm{C}$, with a photoperiod of $12: 12 \mathrm{~h}$ (light:dark) as previously described (Zhou and Wu, 1998). During culture, the flasks were shaken several times by hand at intervals each day, and the Provasoli's enriched seawater (PES) medium (Starr and Zeikus, 1993) was replaced every 2 weeks.

\section{Complementary DNA Cloning of SjNuf2}

Total RNA was extracted from Saccharina gametophytes using TRIzol reagent according to the manufacturer's instructions (Invitrogen, Carlsbad, CA, United States). Complementary DNA (cDNA) was synthesized from the extracted total RNA using the PrimeScript ${ }^{\mathrm{TM}}$ RT Reagent Kit (TaKaRa, Kyoto, Japan). The open reading frame (ORF) of SjNuf2 was amplified with one pair of designed primers Nuf2-U (5'-ATGGGTGATGGCGGGGAC$\left.3^{\prime}\right)$ and Nuf2-D (5'-TCACGTAATCACGGTGGAGGAA-3') based on one screened contig (SJ19509) sequence from a pyrosequencing transcriptome of this kelp (Ye et al., 2015). Twenty-five-microliter reaction volume contained $1 \mu \mathrm{l}$ of the synthesized cDNA, $12.5 \mu 12 \times$ pfu PCR Master Mix (Tiangen Biotech, Beijing, China), $1 \mu l$ each forward and reverse primers Nuf2-U/Nuf2-D $(10 \mu \mathrm{M})$, and $9.5 \mu \mathrm{l}$ distilled deionized $\mathrm{H}_{2} \mathrm{O}$ $\left(\mathrm{ddH}_{2} \mathrm{O}\right)$. Polymerase chain reaction (PCR) was performed in a gradient Mastercycler (Eppendorf, Hamburg, Germany) and programmed as described by $\mathrm{Hu}$ and Zhou (2001) except for the 35 cycles of the reaction and annealing at $67.2^{\circ} \mathrm{C}$ for $1 \mathrm{~min}$. The amplified products were resolved on a $1.0 \%$ low-meltingpoint agarose gel for DNA recovery. The target product was recovered using the agarose gel purification and extraction kit (Aidlab Biotech, Beijing, China) and was ligated to a pMD19$\mathrm{T}$ vector (TaKaRa, Kyoto, Japan). The constructed vector pMD19T-SjNuf2 was subsequently transformed into E. coli DH5 $\alpha$ competent cells (Tiangen Biotech, Beijing, China), and 
several positive clones were sent to Sangon Biotech (Shanghai, China) Co., Ltd., for sequencing.

\section{Bioinformatics Analysis}

The amino acid compositions of the corresponding deduced protein, SjNuf2p, was analyzed online using $\mathrm{NCBI}^{1}$. The molecular weight and isoelectric point of this protein were estimated online using ProtParam ${ }^{2}$. Signal peptide site of SjNuf2p was predicted by SignalP 4.1 Server $^{3}$, while transit peptide site of this protein was predicted by TargetP 1.1 Server $^{4}$ and ChloroP 1.1 Server ${ }^{5}$. The functional domain of SjNuf2 $p$ was predicted using SMART ${ }^{6}$, and its $\alpha$-helical coiled-coil structure was done using Paircoil ${ }^{7}$ (McDonnell et al., 2006). Protein sequences of Nuf2p from different organisms were retrieved from $\mathrm{NCBI}^{8}$. Homologous sequences of Nuf2ps were aligned using ClustalW embedded in MEGA 6.0 program (Tamura et al., 2013), and phylogenetic inference after removal of gaps by hand was constructed using MEGA 6.0 program with the neighbor-joining (NJ) method. The superimposed images of the SjNuf2p tertiary structure were obtained from SWISS-MODEL ${ }^{9}$.

\section{Heterologous Expression and Preparative Polyclonal Antibody of SjNuf2p}

The gene SjNuf2 was cloned by using the primers Nuf2-heU (5'-GGATCCATGGGTGATGGCGGGGAC-3', italic letters showing the recognition site of $B a m \mathrm{HI})$ and Nuf2-heD ( $5^{\prime}$ AAGCTTCGTCACGGTGGAGGAAGGT-3', italic letters denoting the recognition site of HindIII). Twenty-five-microliter reaction volume consisted of $1 \mu \mathrm{l}$ plasmid DNA of pMD19TSjNuf2, $12.5 \mu \mathrm{l} 2 \times$ pfu PCR Master Mix (Tiangen Biotech, Beijing, China), $1 \mu$ l each forward and reverse primers Nuf2-

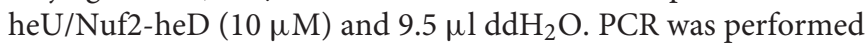
as mentioned above except for the annealing at $73^{\circ} \mathrm{C}$. The target product was ligated into a pET-28a prokaryotic expression vector digested by both BamHI and HindIII. The resulting construct pET28a-Nuf2 was transformed into E. coli BL21 (DE3) competent cells (Tiangen Biotech, Beijing, China). Colony PCR and nucleotide sequencing were performed to confirm the orientation and reading frame of this ligated insert.

The expression of the recombinant protein in transformed $E$. coli cultures was induced by addition of $1 \mathrm{mM}$ isopropyl- $\beta-\mathrm{D}$ thiogalactoside (IPTG) as described by Ye et al. (2014). Crude cell extracts were prepared by sonicating (W220F Ultrasonics, Ningbo, China) cells suspended in phosphate buffer saline (PBS) (0.137 M NaCl, $2.7 \mathrm{mM} \mathrm{KCl,} 10 \mathrm{mM} \mathrm{Na}_{2} \mathrm{HPO}_{4}$, and

\footnotetext{
${ }^{1}$ http://www.ncbi.nlm.nih.gov/

${ }^{2}$ http://www.expasy.org/tool/protparam.html

${ }^{3} \mathrm{http}: / /$ www.cbs.dtu.dk/services/SignalP/

${ }^{4} \mathrm{http}: / /$ www.cbs.dtu.dk/services/TargetP/

${ }^{5} \mathrm{http}: / /$ www.cbs.dtu.dk/services/ChloroP/

${ }^{6} \mathrm{http}: / /$ smart.embl-heidelberg.de/smart/set_mode.cgi?NORMAL=1

${ }^{7}$ http://cb.csail.mit.edu/cb/paircoil2/

${ }^{8} \mathrm{http}: / /$ www.ncbi.nlm.nih.gov/protein/?term=nuf2

${ }^{9}$ https://www.swissmodel.expasy.org/
}

$\left.2 \mathrm{mM} \mathrm{KH}_{2} \mathrm{PO}_{4}\right)$ at $4^{\circ} \mathrm{C}$. Denaturing sodium dodecyl sulfatepolyacrylamide gel electrophoresis (SDS-PAGE) was performed according to Laemmli (1970), and protein was quantified using the Bradford method (Bradford, 1976). Antiserum was obtained from the immunized rabbits with the recombinant protein, which was purified from the transformed $E$. coli with pET28a-Nuf2/BL21 using Bio-Scale ${ }^{\text {TM }}$ Mini Profinity ${ }^{\text {TM }}$ IMAC Cartridges nickel columns (Bio-Rad, Hercules, CA, United States). The antibody was further purified according to the method as described by Olmsted (1981) and Ritter (1991).

\section{Western Blot Analysis}

This anti-SjNuf2 polyclonal antibody was used in Western blot analysis of SjNuf2p. Western blotting procedures were carried out essentially as described by Ye et al. (2014) with slight modifications. The total proteins of the transformed $E$.

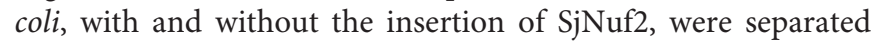
by $12 \%$ SDS-PAGE. After electrophoresis, the proteins were electronically transferred onto nitrocellulose membranes. The protein blot was blocked with $5 \%$ skim milk powder in Trisbuffered saline Tween 20 buffer (TBST; $0.137 \mathrm{M} \mathrm{NaCl}, 2.7 \mathrm{mM}$ $\mathrm{KCl}, 0.025 \mathrm{M}$ Tris, and $0.05 \%$ Tween 20 at pH 7.4) and incubated with the purified antibodies in a suitable dilution at room temperature for $1 \mathrm{~h}$. Next, washed in TBST several times and incubated with a secondary antibody, anti-rabbit IgG labeled by horseradish peroxidase (Youke Biotech, Shanghai, China) diluted 1:1,200 in TBST at room temperature for $1 \mathrm{~h}$ and washed again. The color reaction was visualized with diaminobenzidine following the manufacturer's instructions (Tiangen Biotech, Beijing, China). The Western blot was performed with gradient dilutions of antibody until the blotting signals were strong but less background. Then the Western blotting analysis in female and male gametophytes was performed as above, but the proteins were extracted using the radioimmunoprecipitation assay (RIPA) lysis buffer (Thermo Scientific, Rockford, IL, United States), and the color reaction was developed with SuperSignal ${ }^{\mathrm{TM}}$ West Pico PLUS Chemiluminescent Substrate (Cat. No. 34580) (Thermo Scientific, Rockford, IL, United States) following the manufacturer's instructions.

\section{Paraffin Section and Immunostaining Techniques}

The gametophytes were centrifuged for sampling and kept submerged in $0.1 \%$ colchicine for the observation of metaphase chromosomes at $4^{\circ} \mathrm{C}$ overnight. If the interphase nucleus and tubulin cytoskeleton were observed, the samples were not treated by colchicine. After washing with sterile seawater twice, the collected gametophytes were fixed in the mixture of $1.5 \%$ paraformaldehyde and $0.5 \%$ glutaraldehyde in a $4^{\circ} \mathrm{C}$ fridge overnight. The fixed gametophytes were dehydrated by a gradually increasing ethanol series from 30 through $100 \%$. They were then embedded in paraffin $\left(58^{\circ} \mathrm{C}\right)$ after the routine process of paraffin infiltration in xylene (Jensen, 1962). Paraffinembedded samples were sectioned by a Leica rotary microtome (RM 2235) (Leica Biosystems, Nussloch, Germany) in a thickness of $7 \mu \mathrm{m}$, and sections were placed on poly-D-lysine-coated slides. 
Sections adhered to the coated slides were baked at $25^{\circ} \mathrm{C}$ for $1-2 \mathrm{~h}$ and then at $40^{\circ} \mathrm{C}$ for another $30 \mathrm{~min}$. The baked slides were foiled to avoid light and kept in a $4^{\circ} \mathrm{C}$ fridge if not viewed immediately. Meanwhile, the mitotic metaphase chromosomes were spread on slides after treatment with a mixture of enzymes as described by Liu et al. (2012) as a control.

The stored slides were dried at $60^{\circ} \mathrm{C}$ for $1 \mathrm{~h}$ and dewaxed in two changes of xylene for $10 \mathrm{~min}$ each change and transferred to the mixture of xylene:ethanol $(1: 1, \mathrm{v} / \mathrm{v})$ for another $10 \mathrm{~min}$. These slides were sequentially hydrated in a series of decreased ethanol from absolute ethanol through $30 \%$ to $\mathrm{ddH}_{2} \mathrm{O}$ for $5 \mathrm{~min}$ at a time. The sections were then incubated in a Tris-ethylenediaminetetraacetic acid (EDTA) solution containing $10 \mathrm{mM}$ Tris, $1 \mathrm{mM}$ EDTA, and $0.05 \%$ Tween $20(\mathrm{pH} 9.0)$ at $94^{\circ} \mathrm{C}$ for $20 \mathrm{~min}$ for antigen retrieval. After washing in $1 \times \mathrm{PBST}$ (0.05\% Tween 20 added into PBS) solution containing $0.1 \%$ Triton X-100 three times, 10 min each time, the antigen-repaired slides were placed in a moist chamber and mounted with an appropriate amount of $2 \%$ bovine serum albumin (BSA) at room temperature for $1 \mathrm{~h}$. Air dried later, these slides were incubated for $1 \mathrm{~h}$ with mixtures of primary antibodies, anti-SjNuf2 polyclonal antibody, and anti- $\alpha / \beta$-tubulin antibody (Cat. No. 2148) (Cell Signaling Technology, Danvers, MA, United States), using dilutions that had been established by preliminary titration. Slides were then washed in $1 \times$ PBS three times and incubated in the dark for $1 \mathrm{~h}$ with secondary antibodies conjugated to Alexa Fluor ${ }^{\circledR} 647$ (Cat. No. ab150083) and Alexa Fluor ${ }^{\circledR} 488$ (Cat. No. ab150077) (Abcam, Cambridge, United Kingdom). Slides were then rinsed in $1 \times$ PBS and counterstained by incubation for 10 min with $1 \mu \mathrm{g} \mathrm{ml}^{-1}$ DAPI (Vector Laboratories, Burlingame, CA, United States).

\section{Fluorescence Microscopy and Image Acquisition}

Images were taken with a Leica DM4000 B LED epifluorescene microscope (Wetzlar, Germany) equipped with different filter sets and a digital camera DFC550 (Heerbrugg, Switzerland). Three kinds of fluorescent signals, Alex Flour ${ }^{\circledR} 488$ (green), Alex Flour $^{\circledR} 647$ (red), and DAPI (blue), were detected at the emission wavelength of 519,668 , and $460 \mathrm{~nm}$, respectively. All images were processed using Adobe Photoshop $7.0^{10}$ and Image $J^{11}$ software for color contrast, brightness uniformity, and even the conversion into gray-scale images.

\section{RESULTS}

\section{Characterization of the Coding Sequence of Kinetochore Protein SjNuf2p}

With the designed primers Nuf2-U and Nuf2-D based on one contig (SJ19509) sequence being annotated SjNuf2 in a pyrosequencing transcriptome of $S$. japonica

\footnotetext{
${ }^{10}$ http://www.adobe.com/products/photoshop.html

${ }^{11}$ https://imagej.nih.gov/ij/
}

(Ye et al., 2015), one product, as shown by gel electrophoresis (Supplementary Figure 1), was amplified by PCR. It was recovered and cloned from the electrophoretic gel for sequencing, and it was $1,452 \mathrm{bp}$ in length and deposited in GenBank under accession No. MN242776. BLASTx searching result showed that the similarity of this cloned gene with other Nuf2 genes was interestingly low, and the highest only $58.37 \%$ of identity was found between SjNuf2 and its homolog (GenBank No. CBN74724.1) from Ectocarpus siliculosus that also belonged to brown algae. This is consistent with the low identity of other kinetochore proteins between species, as reviewed by Cheeseman and Desai (2008).

The protein $\mathrm{SjNuf2p}$, encoded by kelp SjNuf2 was predicted to be composed of 483 amino acids with a molecular weight of $53.97 \mathrm{kD}$ and isoelectric point of 8.14. Neither signal peptide nor transit peptide was predicted by the SignalP 4.1 Server or the ChloroP 1.1 Server, indicating that SjNuf2p could work in other than chloroplasts or mitochondria of a kelp cell. TargetP 1.1 Server predication suggested that $S j N u f 2 p$ might reside in the other spaces such as nucleus or cytoplasm because the scores $(0.802)$ were more than those in chloroplast (0.061), mitochondrion (0.115), or secretion pathway (0.148).

Multiple sequence alignment (Figure 1) showed that the amino-terminal sequence of $\mathrm{SjNuf} 2 \mathrm{p}$ was relatively conserved, whereas the carboxyl-terminal sequence varied greatly. This might be interpreted that the main functional domain of Nuf2p was positioned from Tyr-9 to Glu-142 (Figure 1). The other main functional domains included Spc7 (from Ile-103 to Asp411), SPT2 (from Lys-147 to Gln-244), and MIT (from Ser-283 to Arg-348) (Figure 1). Of these domains, Spc7 is a domain of kinetochore protein, which exists in the kinetochore-spindlerelated cytokinin (Kerres et al., 2004). Spc7p is also a component of the NMS (Ndc80-MIND-Spc7) supramolecular complex, and it plays an important role in the late stage of cell meiosis and the whole process of mitosis (Jakopec et al., 2012). SPT2 is one of the domains of chromatin protein and participates in the regulation of histone H3 transcription level (Nourani et al., 2006). The MIT domain forms an asymmetric three-helix bundle, and this domain is found in vacuolar sorting proteins, spastin (probable ATPase involved in the assembly or function of nuclear protein complexes), and a sorting nexin (Takasu et al., 2005), which may play a role in intracellular trafficking.

The reconstructed phylogenetic analysis (Figure 2) inferred from the retrieved 35 Nuf2 proteins illustrated that it was divided into four clades comprising higher plants [bootstrap value $(\mathrm{BV})=100 \%$, archegoniatae $(\mathrm{BV}=100 \%)$, cryptophytes $(\mathrm{BV}=100 \%)$, and algae excluding cryptophytes $(\mathrm{BV}=89 \%)$. In the latter clade, S. japonica situated and constituted the subclade heterokonts $(\mathrm{BV}=56 \%)$ with other related species. The other subclades of this algal cluster excluding cryptophytes were green $(\mathrm{BV}=100 \%)$ and red $(\mathrm{BV}=95 \%)$ algae. As proposed by Gould et al. (2008) and Keeling (2010), heterokonts or stramenopiles including the cultivar of Saccharina might be descended from an ancestor via secondary endosymbiosis when it took up a red alga. That is to say, heterokonts, red and green algae, both of the latter two that were widely accepted as primarily endosymbiotic descendants, possibly evolved from 
Saccharina japonica

Ectocarpus siliculosus (CBN74724)

Nannochloropsis gaditana (EWM29090)

Ostreococcus tauri (XP_003078153)

Arabidopsis thaliana (A $\bar{E} E 33765)$

Saccharomyces cerevisiae (CAA51028)

Homo sapiens (NP_663735)

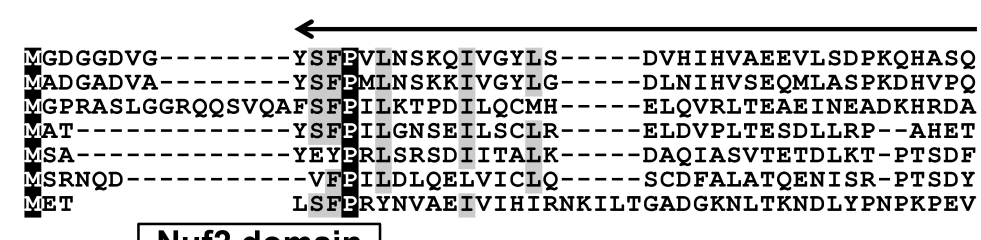

Nuf2 domain

VVMVFEKLVETTMGVTKGEMSOPAFAGLGCLSNPE----LHDDNITFLALFRNVCKMMKI SKIDD-FALKDMSDPTRPRLRRO LTMLFERLVETTLGVTKEEMS PPVFAGLGCL TYPE----LHDES IAFLALFRNVCRMMR I SR IED-FALKDMSDPNQKRLRRQ IRRAYEYLVE I CTGI TKEEMSQPAF S G INALNY PE----LHEE S I PELAFFRACTKMMTVCGVHD-FSMKDLLSPE PKRVRRH LRPCYETLVE IFFGRTLEE ICAPDEKAME TLDYPE---LYTEAI PNLAFIRAMQDLARGCGIDD-FGLKDIFKPEYGRTRRN

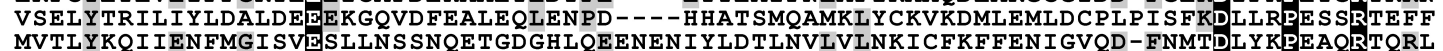
MVTL YKQ I IENFMG I SVESLLNS SNQE TGDGHLQEENEN IY YD TLNVLVLNK ICFKFFEN IGVQD-FNMTDIYKPEAQRTQRL
LHMIYMRALQIVYGIRLEH FYMMPVN--SEVMYPH----LMEGFLPF SNLVTHLDSFLPICRVND-FETADILCPKAKRT SRF

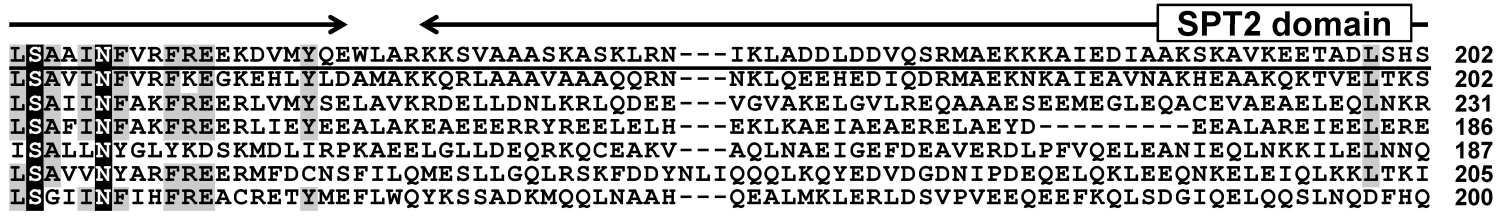
L CSVVREEGAQLKKANF-AAKDKVAS SMAALKQAEVEKERLQGQVVNSPQRILREVADQQQALDQELADVQAELQNTQKLQQSV 284 VGTAREELARVKKDNN-D IKDRVATAQATLNRAELEKKNLQAQVVSSPKRILREVSDIQQSLEQELSEVEAETRKAQSFKHSV 284 QAE IRAQGAE LKKQSQ-DLKE S IGKAS SALESGIEEREKTRGQIVRSPERVRRELASAAEEVETEKKEGLATERDAREMHLRV 313 VEAATLEANRVEAEAV-AAQN------ELQSLESEGEQLRQHMENLELEKASAASEEAHLIEQERQE------AEKLAEQV 254 QMSLRATFQKMREKST-QMDNE I SKAE FDIVETVQENANLRSQIVQSPDKLQGALEEKKLVLGETKKAEQSAMVTFQEKAAIL 279 QETL S ID YND YKI SKQ-S IFKDLEAL SFQIVELESNRDKL I KI SNTDMEEL SEGIKELNDLI IQRKKTLDDLTAQQKNLQDTV 287 KT IVLQE GN SQKKSNI SEKTKRLNELKL SVVSLKE IQE SLKTKIVD SPEKLKNYKEKMKD TVQKLKNARQEVVEKYE IYGDSV 283

\begin{tabular}{|c|c|}
\hline $\begin{array}{l}\text { VVLGRAKRELVKAAAS IEEAGTELSKQESAYKEV } \\
\text { VVMNKARRELAKATAN IEEAATELSKQESAMREV } \\
\text { QAVQKGEKEVGKAIKALEEIEGEMAKVKLASKEL } \\
\text { KHLKMMEEDLREA IMKSIEQKRAQTEEEKLKL } \\
\text { EVFEKALKKILKSSSQLQL INEQVTNAKTVEKE F } \\
\text { TTFETI ISELYDVLRI ISSEVQE SNRTETELVGL } \\
\text { DCLPSCQLEVQLYQKKIQDLSDNREKLASILKES }\end{array}$ & $\begin{array}{l}\text { KSTQRKIVEKRGEYAAR--ASE I SENQRRLVRLEEKLFHLQKQAAFKTE } \\
\text { KNTQYKIHEKRNDFATR--SSEKAELQRRLVRFEEKLAHLRKQAAFKTE } \\
\text { LDATKNVQGNRQRVLEA--AQEMENLKRQASRFEDRWTHLRKSGKAKDE } \\
\text { LHVEEEIASKEEEMWKM--DAKIEQLQRQKEAMDEKMTRMREQGKLKIE } \\
\text { RHALKDKLSEDGVAYKSL--EAKVVERERIVEQLNE SLKQLEKEKAVMFD } \\
\text { KQNLINNKLKLMNVLETGIMYKLE ILEQLDLLKNLEKLSQDTKESR } \\
\text { LNLEDQIESDESELKKL--KTEENSFKRLMIVKKEKLATAQFKINKKHE }\end{array}$ \\
\hline
\end{tabular}

FIGURE 1 | Multiple sequence alignment of Nuf2ps from several organisms. Conserved residues and the residues with $70 \%$ identity are highlighted in black and gray, respectively. The underlined indicates Spc7 domain.

ancestors with a plastid of different origins (Keeling, 2010). Accordingly, red algae should be located at the base of this algal clade as shown in the constructed phylogenetic tree (Figure 2), followed by heterokonts but not green algae. This confused phylogenetic relationship between green algae and heterokonts could be interpreted that Nuf2p might be encoded by a much conserved homologous gene in the two assumed eukaryotic ancestors for primary or secondary endosymbiosis, thus showing its evolutionary conservation in function.

Although SjNuf2p had low identity with its homologs in amino acid sequence, they all possessed special functional domains such as Nuf2, Spc7, SPT2, and MIT domains, indicating that their structures and functions were quite conserved, as suggested by Cheeseman and Desai (2008). Moreover, $\alpha$-helical coiled-coil structure, which was present in yeast and human Nuf2p (Osborne et al., 1994; Wei et al., 2005), was predicted using Paircoil2, and this structure was built by five fragments that spanned the amino acid sequence of $\mathrm{SjNuf} 2$ p from 155 to 201, 211 to 248,250 to 320,330 to 360 , and 384 to 421 sequentially.

\section{Heterologous Expression of SjNuf2 in Escherichia coli}

One pair of primers Nuf2-BamHI-U and Nuf2-HindIII-D was designed on the basis of $\mathrm{SjNuf} 2 \mathrm{ORF}$ sequence. The size of the amplified product with these primers was $1,464 \mathrm{bp}$ (Lane 1 in Supplementary Figure 2) as expected after cloning and sequencing. This product was ligated to generate the vector pMD-19T-SjNuf2. Both pMD-19T-SjNuf2 and the vector pET-28a were digested separately by the combined restriction endonucleases BamHI and HindIII (Lanes 2 and 3 in Supplementary Figure 2). The recombinant vector pET$28 \mathrm{a}-\mathrm{SjNuf} 2$ was then constructed by T4 ligase, and it was transformed into E. coli $\mathrm{DH} 5 \alpha$ competent cells for duplication. The construct pET-28a-SjNuf2 was extracted and sequenced for clarification and subsequently was transformed into the competent cells of E. coli BL21 (DE3) to obtain the transgenic E. coli strain 28a-SjNuf2-BL21. The construct pET-28a-SjNuf2 was extracted from the transgenic strain and digested by BamHI and HindIII for verification. Two digested products were generated as shown by agar gel electrophoresis (Lane 4 in Supplementary Figure 2). One was identical with the length (about $5.5 \mathrm{~kb}$ ) of digested pET-28a (Lane 3 vs. 4 in Supplementary Figure 2), and the other was the same size (approximately $1.5 \mathrm{~kb}$ ) as the target genes (Lane 1 vs. 4 in Supplementary Figure 2). This digestion pattern and sequencing analysis of the target gene (data not shown) suggested that the prokaryotic expression vector carrying SjNuf2 that was fused with six residues of histidine at the amino terminus was constructed as designed. 


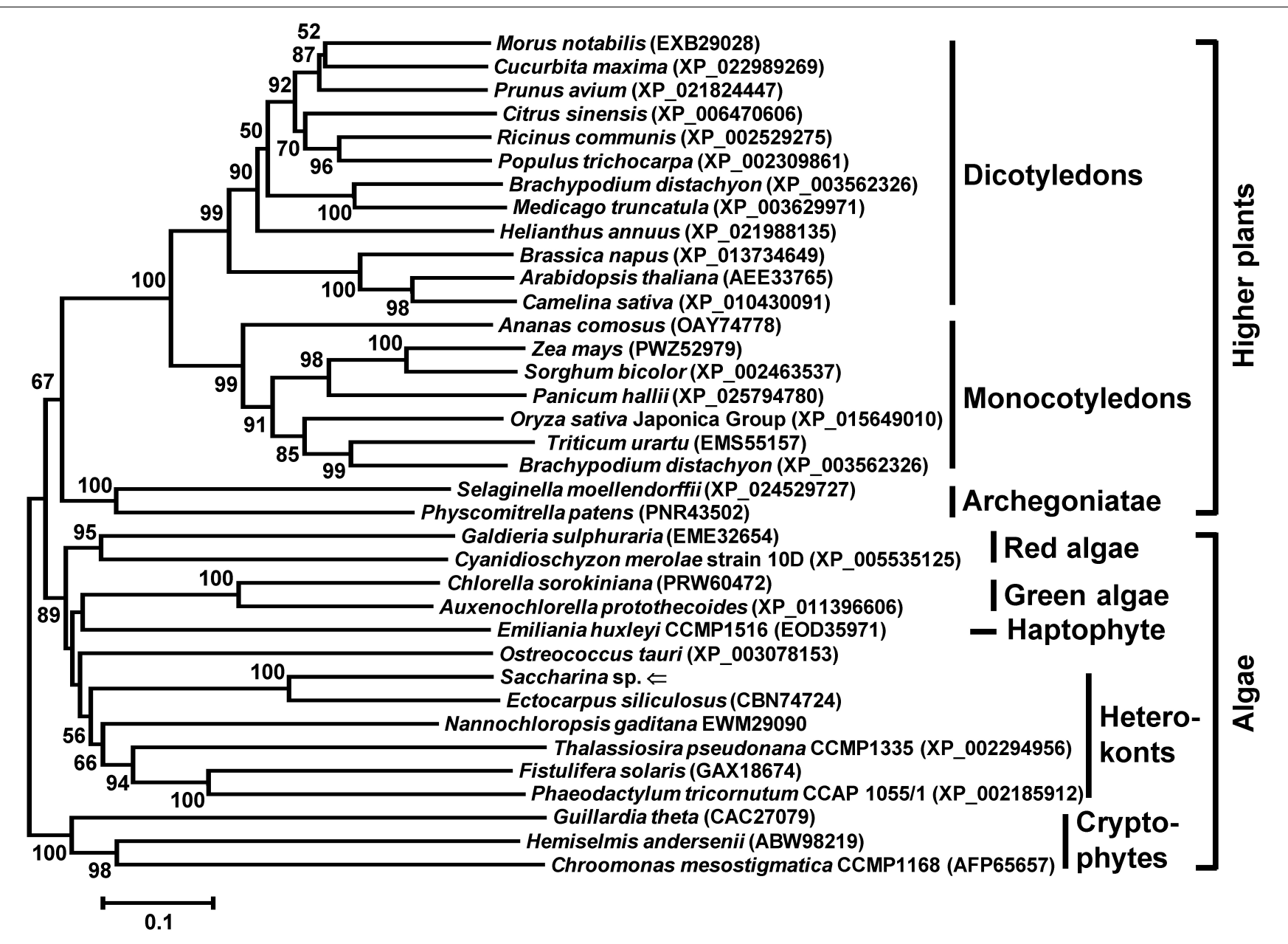

FIGURE 2 | Neighbor-joining phylogenetic tree inferred from the deduced amino acid sequences of Nuf2 genes from different species of organisms. This phylogenetic tree was reconstructed by 279 amino acids after removal of gaps by hand. All of the accession numbers are presented in parentheses after the Latin names. Branch lengths are proportional to the number of substitutions per site (see the scale bar). The numbers at the nodes indicate the neighbor-joining bootstrap values (BV) (only values $\geq 50 \%$ are shown). The Nuf2p from the Saccharina cultivar is marked by an arrow.

Isopropyl- $\beta$-D-1-thiogalactopyranoside was added to the culture of transgenic strains 28a-SjNuf2-BL21 and 28a-BL21 to induce the expression of target gene. The intact cells of these two transgenic lines were employed to SDS-PAGE analysis. An extra band at approximately $60 \mathrm{kD}$ was present in the strain harboring SjNuf2 while comparing to the other transgenic one 28a-BL21 carrying the empty vector pET-28a alone (Lane 1 vs. 2 in Supplementary Figure 3). Moreover, this band was inducibly expressed by addition of IPTG as comparing Lanes 3 and 4 in Supplementary Figure 3. This band, however, looked larger than the encoded protein of SjNuf2 in size $(53.97 \mathrm{kD}$ estimated in theory), since 52 amino acids $(5.41 \mathrm{kD}$ estimated theoretically) including $6 \times$ His-tag were fused at the aminoterminal of SjNuf2p. The 52 -amino acid peptide was encoded by the nucleotides upstream of BamHI of expression vector pET28a. Therefore, this band might be the recombinant protein according to the size of estimated molecular weight. To further confirm this, $6 \times$ His-tag-labeled protein polyclonal antibody was used to detect the extracted proteins from the transformed strain harboring SjNuf2 by Western blotting analysis. At approximately $60 \mathrm{kD}$ corresponding to the standard molecular weight of proteins, one immunoblotting signal exclusively emerged (Lane 5 in Supplementary Figure 3). Collectively, these results indicate that Nuf2p of the Saccharina cultivar has been heterologously expressed in E. coli.

\section{Purification of Recombinant SjNuf2p and Its Polyclonal Antibody}

Both precipitation and supernatant of the broken transgenic strain 28a-SjNuf2-BL21 were separately collected after centrifugation and resolved by SDS-PAGE analysis. The electrophoresis profile demonstrated that $r S j N u f 2 p$ was expressed mainly in the form of inclusion bodies (Lane 2 in Supplementary Figure 4). To obtain a large amount of rSjNuf2p for antibody generation, the inclusion bodies were dissolved with $8 \mathrm{M}$ urea, and the resulting sample was loaded to IMAC nickel column for affinity chromatography purification 
using the fused $6 \times$ His-tag with $\mathrm{rSjNuf} 2 \mathrm{p}$. Compared with the elution buffers containing low concentrations of imidazole $(5,10,20$, and $30 \mathrm{mM}$ ) (Lanes $4,5,6$, and 7 , respectively, in Supplementary Figure 4), 250-mM imidazole buffer could be used to purify the recombinant protein so that the target band was predominant (Lane 8 in Supplementary Figure 4). After elution with $250-\mathrm{mM}$ imidazole buffer, the remainder in the column was less (Lane 9 in Supplementary Figure 4). Therefore, rSjNuf2p can be purified by using the denatured elution buffer comprising $250 \mathrm{mM}$ of imidazole for animal immunization to produce the corresponding antibody.

The affinity-purified $\mathrm{rSjNuf2} \mathrm{p}$ was employed to immunize New Zealand white rabbits. After immunization, antiserum was collected from the immunized rabbits. The titer of antiSjNuf2 polyclonal antibody in the antiserum was $1.024 \times 10^{6}$ as determined by indirect ELISA assay, thus suggesting that it could meet the requirements of subsequent experiments. Prior to quality detection, this prepared antibody was purified further with the purified $\mathrm{rSjNuf} 2 \mathrm{p}$.

\section{Co-localization of SjNuf2p With $\alpha / \beta$-Tubulin on Saccharina Chromosomes}

The purified anti-SjNuf2 polyclonal antibody was used to detect the total extracted proteins from Saccharina gametophytes by Western blot analysis. The immunoblotting pattern demonstrated that only one signal was present at around $54 \mathrm{kD}$ (Lane 2 in Figure 3). The location of this blotting signal corresponding to $54 \mathrm{kD}$ coincided with the predicted molecular weight of SjNuf2p (53.97 kD), suggesting the high quality of purified polyclonal antibody. In addition, this Western blotting result supported the absence of signal and transit peptides in SjNuf2p, as predicted by SignalP and ChloroP Servers.

Meanwhile, the commercially supplied anti- $\alpha / \beta$-tubulin polyclonal antibody was tested using Western blot analysis with the total extracted proteins from Saccharina gametophytes. The blotting signals of $\alpha / \beta$-tubulin looked weaker than that of SjNuf2p (Lane 3 vs. 2 in Figure 3) possibly due to the visualized reactions using diaminobenzidine rather than the more sensitive Pico PLUS Chemiluminescent Substrate used for SjNuf2p analysis. From the blotting profile (Lane 3 in Figure 3), two blotting signals were found to be present in the total proteins of the cultivar gametophyte of Saccharina. One signal emerged at about $50 \mathrm{kD}$ as estimated according to the standard proteins, and this size was consistent with the theoretical molecular weight of $\alpha$ - and $\beta$-tubulins deduced from their full-length mRNA sequencing data of this kelp (Bi et al., 2019; Supplementary Data 1, 2). The other signal corresponded to a protein with its molecular weight of about $40 \mathrm{kD}$. From the full-length mRNA sequencing data of this kelp (Bi et al., 2019), we also searched two $\beta$-tubulin genes that encoded proteins with their molecular weight near $40 \mathrm{kD}$ (Supplementary Data 3, 4). These two $\beta$-tubulin proteins had $84.27 \%$ identity with the larger one $(50 \mathrm{kD})$ in amino acid sequence, and all the four tubulin proteins had $73.36 \%$ identity with each other (Supplementary Figure 5). Apparently, these pieces of information about kelp $\alpha$ - and $\beta$-tubulin genes needed to be confirmed by further experiments, though their molecular weights in size seem to be consistent with this blotting analysis (Lane 3 in Figure 3).

Prior to observations on the location of SjNuf2p on the kelp chromosomes, the interphase nucleus was checked. In the given image (upper panel in Supplementary Figure 6) of an interphase nucleus incubated with the purified antiSjNuf2 polyclonal antibody, four distinguishable signals were present, showing that $\mathrm{SjNuf2p}$ was possibly concentrated on the chromatins. The number of signals was inconsistent with the haploid number chromosomes $(n=31)$ of this kelp gametophyte (Liu et al., 2012) possibly because the (peri)centromeric heterochromatin association was prevented by chromatin compactness (Schubert et al., 2013). To co-localize SjNuf2p and tubulin with their corresponding antibodies, the secondary antibodies were conjugated to Alexa Fluor ${ }^{\circledR} 488$ and Alexa Fluor ${ }^{\circledR}$ 647, respectively. After immunostaining, the tubulin cytoskeleton was observed to be spread rather than spindle-like possibly due to the interphase nucleus of kelp gametophytic cells treated without colchicine (Figure 4), but SjNuf2p was found to be outside of the DAPI-stained nucleus different from the observation in the previous interphase nucleus (upper panel in Supplementary Figure 6). These localization patterns (Figure $\mathbf{4}$ and Supplementary Figure 6) were similar to those as reported by Hori et al. (2003), and Figure 4 might be for G1/S and Supplementary Figure 6 for late G2 of interphase nuclei at different stages. In the samples treated without colchicine (Figure 4 and upper panel in Supplementary Figure 6), it was difficult to find a distinguishable chromosome due to fewer nuclei at the metaphase stage and smaller size of kelp chromosomes (Liu et al., 2012). Accordingly, the gametophytes were treated with colchicine in order to determine the precise location of SjNuf2p on chromosomes.

In the section of kelp gametophytes at metaphase immunostained only with the purified anti-SjNuf2 polyclonal antibody (lower panel in Supplementary Figure 6), eight of the 15 chromosomes, each had only one clear signal, suggesting that $\mathrm{SjNuf2p}$ might reside at the kelp centromeres. Similarly, in the given paraffin section co-stained with antiSjNuf2 and $\alpha / \beta$ tubulin antibodies (Figure 5), there are 23 chromosomes as stained by DAPI, and they resembled the previously reported chromosomes in appearance (Liu et al., 2012). Immunofluorescence signals were present on nine chromosomes (Figure 5), which accounted for 39\% of the observed chromosomes. On these nine chromosomes, when the green signal ( $\mathrm{SjNuf} 2 \mathrm{p})$ presented, the red signal ( $\alpha / \beta$-tubulin) emerged, suggesting that they were co-localized at the same sites. Because the chromosomes fixed on the slides were sectioned instead of spread, the antigen on these chromosomes (i.e., centromeres) was not so much exposed at the same focal plane to its corresponding antibodies for immunological reaction that not all the chromosomes possessed the immunological signals. Two of these nine chromosomes were selected for a detailed illustration due to the presence of constricted regions as stained by DAPI (DAPI image in Figure 5). The enlarged images of the two chromosomes (merged image in Figure 5) indicated that 


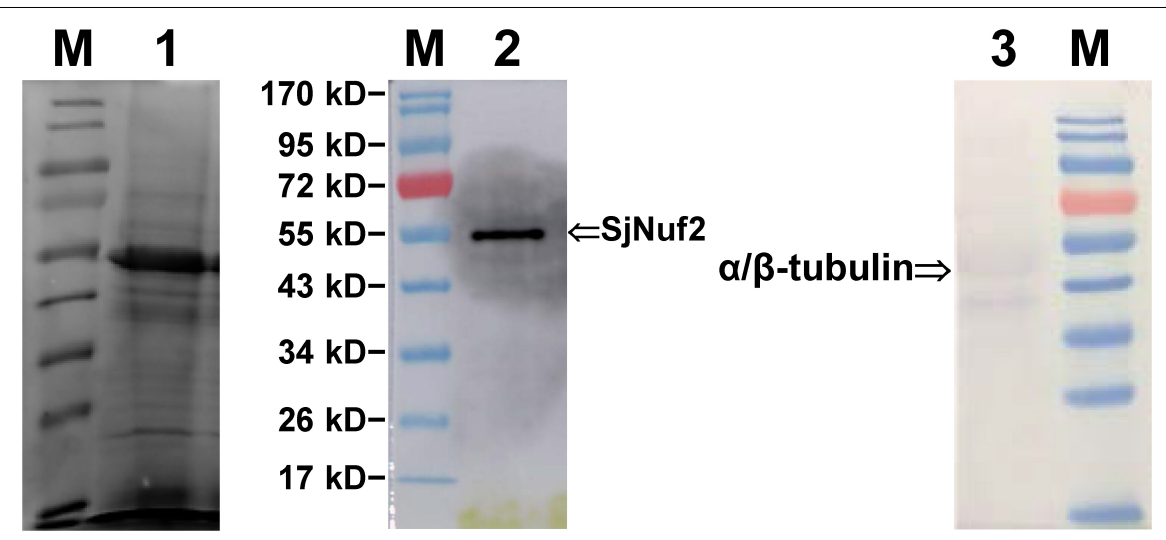

FIGURE 3 | Western blot profiles of the total proteins extracted from Saccharina gametophytes. Lane M, PageRuler Prestained Protein Ladder (Thermo Scientific, Shanghai, China); Lane 1, electrophoresis profiles of the total extracted proteins using radioimmunoprecipitation assay (RIPA) buffer; Lanes 2 and 3 , the blotting signals as stained with anti-SjNuf2 and anti- $\alpha / \beta$-tubulin antibodies, respectively.

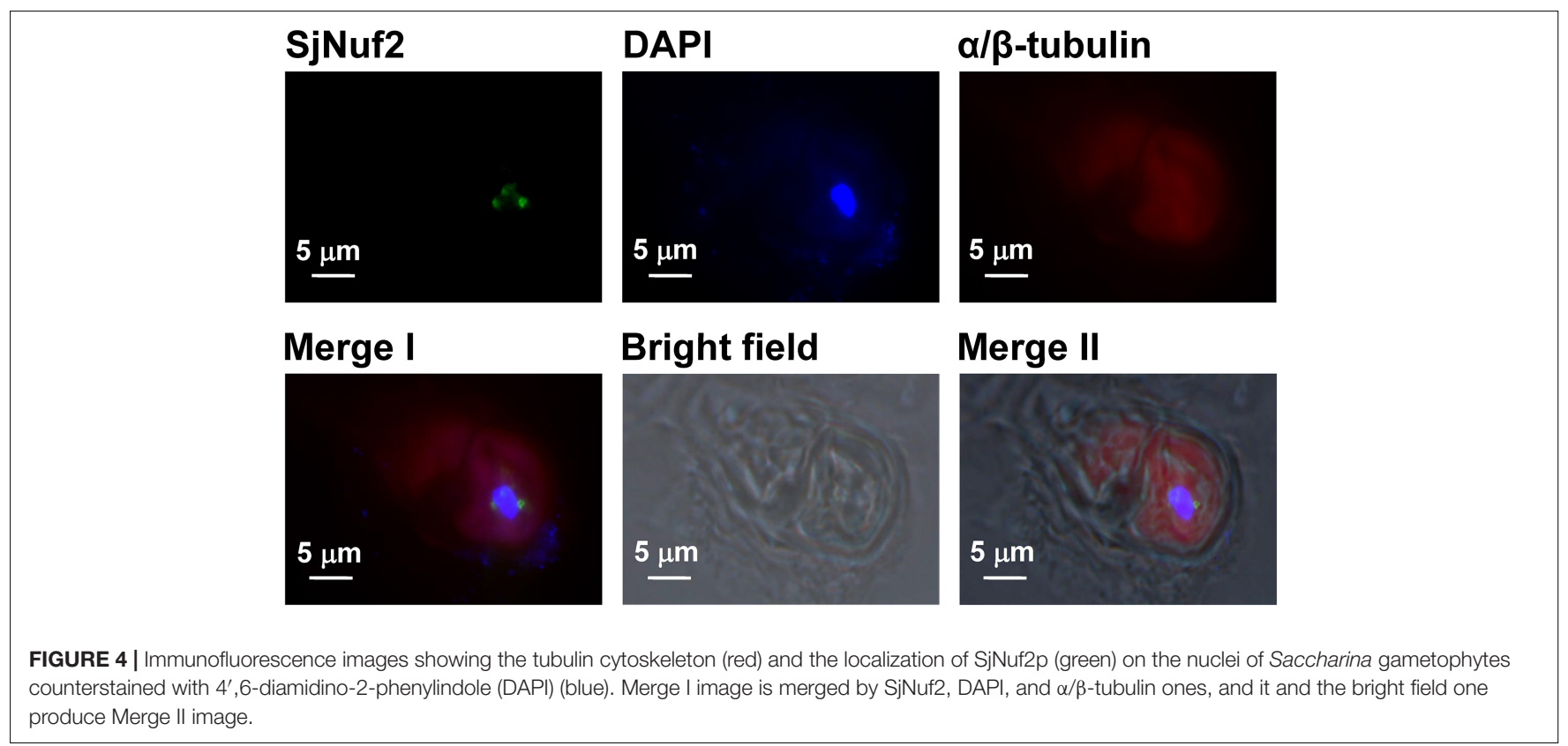

both green ( $\mathrm{SjNuf2} \mathrm{p})$ and red $(\alpha / \beta$-tubulin) signals resided at the primary constrictions. This immunolocalization pattern not only identified SjNuf2p, which was one of kinetochore proteins assembled at centromeres as well in yeast and human, but also provided cytogenetical evidence that $\mathrm{SjNuf2}$ p was considered as a centromere marker for karyotype analysis in kelp. In addition, this result verified definitely that $\mathrm{SjNuf} 2 \mathrm{p}$ worked in the kelp nucleus rather than the cytoplasm, thus replying the prediction of subcellular localization as mentioned above.

In the kelp haploid gametophytes, the mitotic metaphase chromosomes are composed of two sister chromatids. If SjNuf2p worked at the centromeres, the green fluorescence signals of this protein should emerge at the primary constrictions as an opposite pair (Suzuki et al., 1997). Nevertheless, this expected distribution of $\mathrm{SjNuf2p}$ on chromosomes was not observed in Figure $\mathbf{5}$ and Supplementary Figure 6. To avoid the potent negative effect of sectioned slides, squashed chromosomes after treatment with mixture of enzymes were used for immunostaining. The immunostained images (Supplementary Figure 7) illustrated that most green signals ( $\mathrm{SjNuf2p}$ ) were located in the same manner as shown in Figure 5 and Supplementary Figure 6, except for three chromosomes that showed the symmetric distribution of green signals (SjNuf2p): one was metacentric and two were telocentric. But the tubulin signals, unfortunately, were not observed in the squashed slides (Supplementary Figure 7), suggesting that the kinetochore-microtubule complex would be destroyed during the chromosome preparation with various enzymes. Accordingly, the asymmetric location of $\mathrm{SjNuf} 2 \mathrm{p}$ on the kelp chromosomes in Figure 5 and Supplementary Figures 6, 7 was supposed to be that the chromosomes were not observed longitudinally or that the other opposite kinetochore was not assembled well or destroyed during the chromosome preparation. 


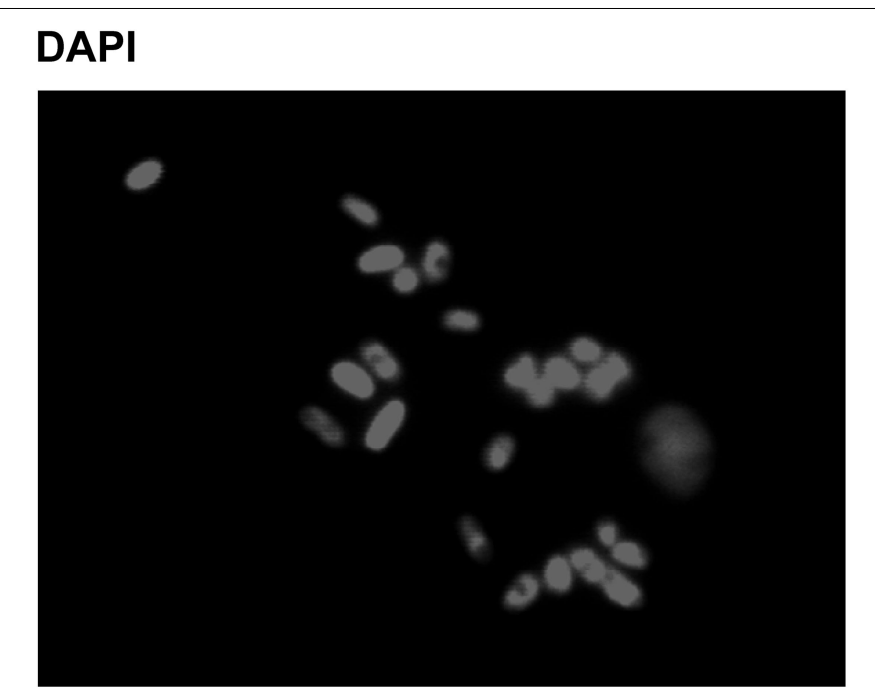

\section{SjNuf2}

\section{$\alpha / \beta$-tubulin}

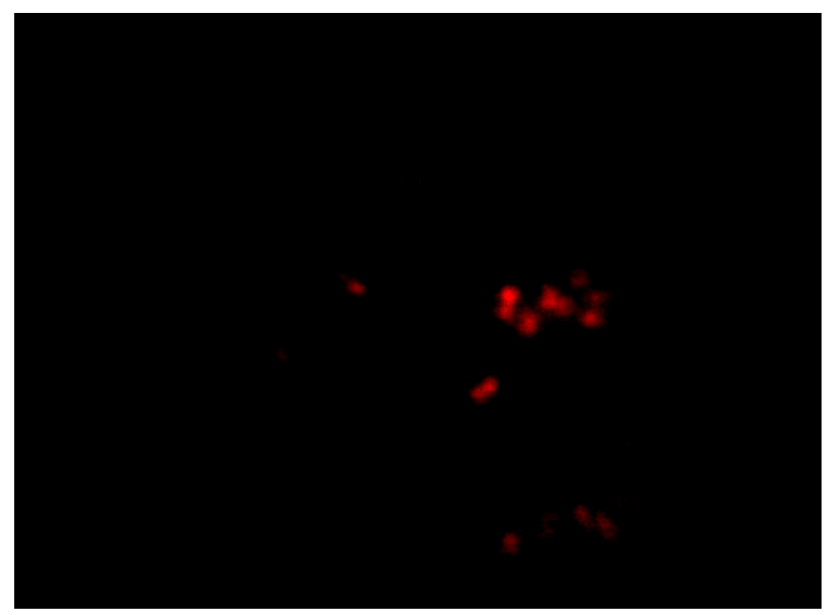

FIGURE 5 | Immunofluorescence images showing the co-localization of SjNuf2p (green) and $\alpha / \beta$-tubulin (red) on Saccharina cultivar chromosomes counterstained with $4^{\prime}, 6$-diamidino-2-phenylindole (DAPI) (gray). The insets in the merged image clearly illustrating that the signals are present at the centromeres of two selected chromosomes as indicated by arrowheads.

\section{DISCUSSION}

According to our previous explorations of kelp cytogenetics using FISH technique (Liu et al., 2012; Liu et al., 2017; Yang et al., 2017), we propose that centromere is a breakthrough point for karyotype analysis of $S$. japonica. A lot of publications uncover the varied centromeric DNA in different organisms, but the kinetochore proteins assembled at the centromeres are evolutionarily conserved (Richards and Dawet, 1998; Jiang et al., 2003; Przewloka and Glover, 2009; Comai et al., 2017). Thus, the attachment of Nuf2p, one component of the Ndc80 complex, with microtubules for the segregation of chromosomes in mitosis (Osborne et al., 1994; Nabetani et al., 2001; DeLuca et al., 2002; Ciferri et al., 2008; Sundin et al., 2011; Shin et al., 2018) drew our attention.
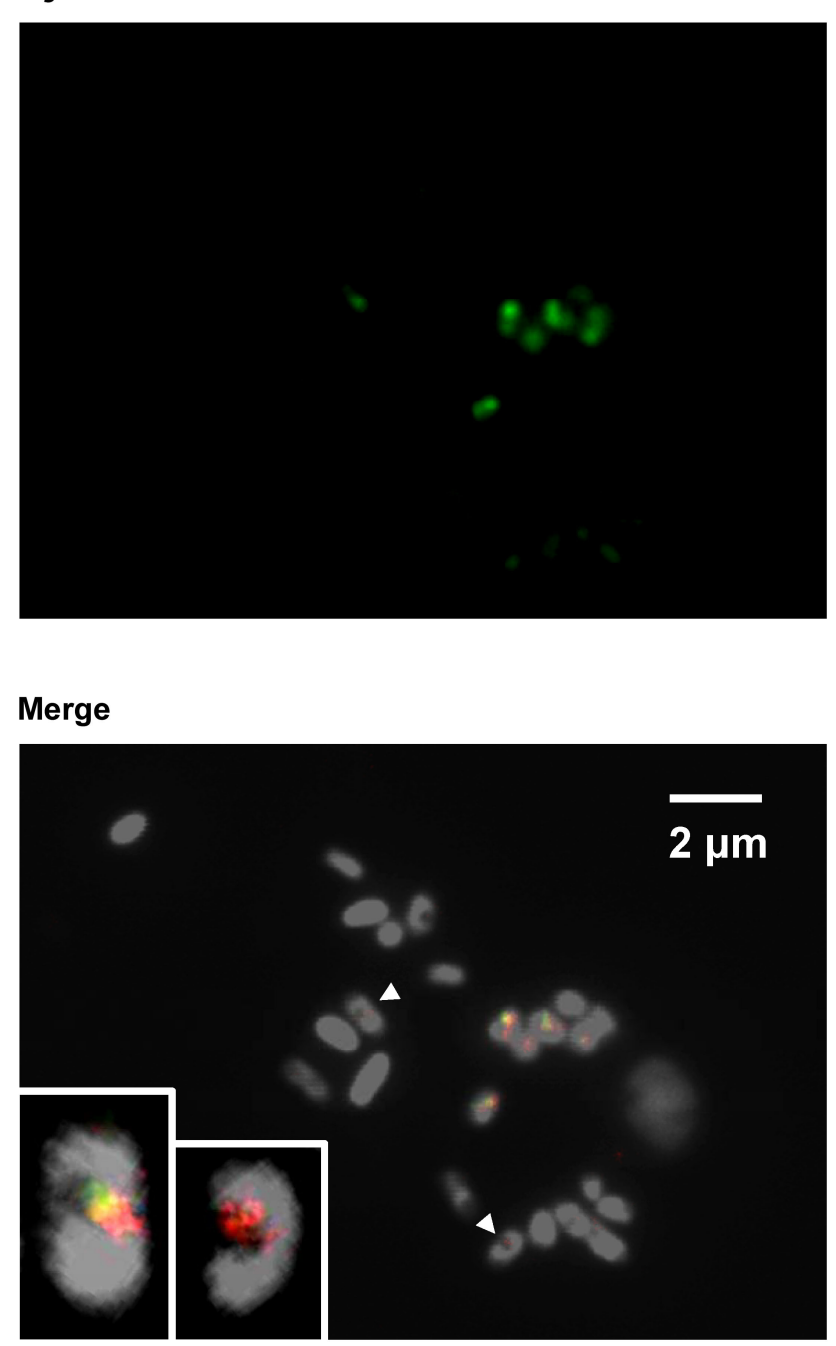

\section{Merge}

After gene cloning of SjNuf2 from the gametophytes of a Saccharina cultivar, we knew it encoded a protein consisting of 483 amino acids. Multiple sequence alignments (Figure 1) illustrated that, amino acid sequences of Nuf2ps were not so identical among the organisms that SjNuf2p was only 58\% identical with its homolog from Ectocarpus siliculosus that is classified as Phaeophyta with Saccharina. However, SjNuf2p is characterized by a Nuf2 domain (Figure 1) and a coiled-coil structure as predicted using the online available software. In addition, SjNuf2p has the domains of Spc7, SPT2, and MIT, as predicted using SMART, but their E-values (17,600, 25,400, and 281,000, respectively) are less significant than established cutoffs. Moreover, a calponin homology $(\mathrm{CH})$ domain for actin binding has been reported to be present in humans HsNuf2p (Ciferri et al., 2008; Sundin et al., 2011) but absent in SjNuf2p, as predicted using all the available software. This possibly results 
from limited information about Nuf2p in the public protein database. To provide better evidence, the homology modeling of SjNuf2p (Supplementary Figure 8), superimposed with human HsNuf2p as a reference, illustrates that $S j N u f 2 p$ is much more matched with HsNuf2p, thus suggesting that Nuf2p would be highly conserved in structure and consequently in function. The structural and functional conservation is also supported by the phylogeny inferred from the Nuf2 proteins (Figure 2), though they are not highly identical in the primary sequence of amino acids (Figure 1).

Based on the abovementioned reports that Nuf2p connects microtubules with chromosomes at the centromeres, we can use the commercial anti- $\alpha / \beta$-tubulin antibody to identify the gene SjNuf2 by immunolocalization. Obviously, the antiSjNuf2p antibody is the first thing to get ready for this study. Upon heterologous expression of SjNuf2 in E. coli, the rSjNuf2p was prepared and detected (Supplementary Figures 24). Then, the anti-SjNuf2 polyclonal antibody was raised against the purified rSjNuf2p by immunizing New Zealand rabbits. The specificity of the generated anti-SjNuf2 polyclonal antibody was determined by Western blotting analysis with the crude extracts from the cultivar gametophytes of Saccharina (Figure 3). Immunolocalization images (Figures 4, 5) of SjNuf2p and $\alpha / \beta$-tubulin as stained with their antibodies illustrated that $\mathrm{SjNuf2} \mathrm{p}$ was co-localized with $\alpha / \beta$-tubulin on the same sites of kelp chromosomes, especially the two selected chromosomes (Figure 5) provided observable evidence that both immunofluorescence signals emerged at the centromeres. In addition, the green signals of $S j N u f 2 p$ emerged at the primary constriction of a few chromosomes as an opposite pair (Supplementary Figure 7). SjNuf2p was proposed to be bound with microtubules at the kelp centromeres, resembling those in yeasts (Osborne et al., 1994; Nabetani et al., 2001; Wigge and Kilmartin, 2001; Asakawa et al., 2005), humans (DeLuca et al., 2002; Liu et al., 2007), and Arabidopsis (Ramahi, 2012; Shin et al., 2018). This architecture of the kinetochore microtubule interface was inferred to be a little resistant to the effect of depolymerization by colchicine (Morejohn and Fosket, 1991) from the red immunofluorescence signals of microtubules on the chromosomes after treatment with colchicine (Figure 5). The resistance to this chemical might owe to the occurrence of a protein termed CLASP, which was reported to suppress microtubule catastrophes (Aher et al., 2018), at the outer kinetochore (Maiato et al., 2004).

To our knowledge, this is the first report on Nuf2p in algae. There is any difficulty to overcome, for example, the emergence of $40-\mathrm{kD}$ signal in the Western blot profile (Figure 3) as immunoblotted with the commercially available anti- $\alpha / \beta$-tubulin antibody. Based upon the generally accepted high identity in $\alpha / \beta$-tubulin amino acid sequences (at least $89 \%$ for $\alpha$-tubulin while $87 \%$ for $\beta$-tubulin) (Fosket and Morejohn, 1992) and the high identity as reflected by multiple sequence alignment of the selected $\alpha / \beta$-tubulin genes (Supplementary Figure 5), at least four genes are proposed in $S$. japonica to encode the $\alpha / \beta$-tubulin proteins of these two immunoblotting signals. Two genes (one is $\alpha$ and the other is $\beta$ ) code for the $50-\mathrm{kD}$ tubulin, and the other two (both are $\beta$ ) for the $40-\mathrm{kD}$ one.
In addition, the immunofluorescence signals are so smeared but not concentrated on the kelp chromosomes (Figure 5) that it is not easy to consider SjNuf2p as a marker directly for the karyotype analysis. However, as SjNuf2p resides at the kelp centromeres as described by the present study, this purified anti-SjNuf2 antibody could be employed to obtain the centromeric DNA using chromatin immunoprecipitation assay. Or if a candidate for the centromeric DNA is available, SjNuf2p could help to determine whether this candidate is or not localized at the kelp centromeres by FISH and immunocytostaining. The determination of centromeric DNA facilitates the identification, ratio estimates of long to short arms and pairing of the kelp chromosomes with the help of telomere and rRNA gene sequences, as documented by Yang et al. (2017) and Liu et al. (2017), respectively. Therefore, the present study will lay a solid foundation for subsequent karyotype analysis of this kelp using FISH technique. Karyotype analysis can provide an important basis for the cytogenetical classification, the relationships among species, and the variations of chromosome number and structure, with an emphasis on the distinctions between female and male chromosomes of this kelp as reviewed by Bi and Zhou (2014).

\section{DATA AVAILABILITY STATEMENT}

The datasets analyzed for this study can be found in the NCBI database under accession numbers listed in Figure 2.

\section{AUTHOR CONTRIBUTIONS}

W-SD carried out most of the experiments, for example, PCR, heterologous expression, and immunofluorescence. P-FL conducted PCR and Western blot experiments for verification and analyzed all of the bioinformatics. YL and YD repeated the immunocytochemistry. Y-HB analyzed all of these data with $\mathrm{P}-\mathrm{FL}$ and confirmed the results in addition to the primary writing of this manuscript. Z-GZ made a significant contribution to the conceptual design of the work and the writing of this manuscript. All authors contributed to the article and approved the submitted version.

\section{FUNDING}

This work was supported by the National Natural Science Foundation of China (grant no. 41376136 to Z-GZ), the National Key Research and Development Program of China (grant no. 2018YFD0901500 to Y-HB), and World Class Discipline Project of Aquaculture (to Z-GZ).

\section{SUPPLEMENTARY MATERIAL}

The Supplementary Material for this article can be found online at: https://www.frontiersin.org/articles/10.3389/fmars. 2020.539260/full\#supplementary-material 


\section{REFERENCES}

Aher, A., Kok, M., Sharma, A., Rai, A., Olieric, N., Rodriguez-Garcia, R., et al. (2018). CLASP suppresses microtubule catastrophes through a single TOG domain. Dev. Cell 46, 40-58. doi: 10.1016/j.devcel.2018.05.032

Asakawa, H., Hayashi, A., Haraguchi, T., and Hiraoka, Y. (2005). Dissociation of the Nuf2-Ndc80 complex releases centromeres from the spindle-pole body during meiotic prophase in fission yeast. Mol. Biol. Cell 16, 2325-2338. doi: 10.1091/mbc.E04-11-0996

Bi, Y.-H., Li, J.-L., and Zhou, Z.-G. (2019). Full-length mRNA sequencing in Saccharina japonica and identification of carbonic anhydrase genes. Aquacult. Fish. 4, 53-60. doi: 10.1016/j.aaf.2018.11.002

Bi, Y.-H., and Zhou, Z.-G. (2014). What does the difference between the female and male gametophytes of Saccharina japonica remind us of? Algol. Stud. 145/146, 65-79. doi: 10.1127/1864-1318/2014/0145

Bradford, M. M. (1976). A rapid and sensitive method for the quantification of microgram quantities of protein utilizing the principle of protein-dye binding. Anal. Biochem. 72, 248-254. doi: 10.1016/0003-2697(76)90527-3

Cheeseman, I. M., and Desai, A. (2008). Molecular architecture of the kinetochore microtubule interface. Nat. Rev. Mol. Cell Biol. 9, 33-46. doi: 10.1038/nrm2310

Ciferri, C., Musacchio, A., and Petrovic, A. (2007). The Ndc80 complex: hub of kinetochore activity. FEBS Lett. 581, 2862-2869. doi: 10.1016/j.febslet.2007. 05.012

Ciferri, C., Pasqualato, S., Screpanti, E., Varetti, G., Santaguida, S., Reis, G. D., et al. (2008). Implications for kinetochore-microtubule attachment from the structure of an engineered Ndc80 complex. Cell 133, 427-439. doi: 10.1016/j. cell.2008.03.020

Comai, L., Maheshwari, S., and Marimuthu, M. P. A. (2017). Plant centromeres. Curr. Opin. Plant Biol. 36, 158-167. doi: 10.1016/j.pbi.2017.03.003

DeLuca, J. G., Moree, B., Hickey, J. M., Kilmartin, J. V., and Salmon, E. D. (2002). hNuf2 inhibition blocks stable kinetochore-microtubule attachment and induces mitotic cell death in HeLa cells. J. Cell Biol. 159, 549-555. doi: $10.1083 /$ jcb.200208159

Evans, L. V. (1963). A large chromosome in the Laminarian nucleus. Nature 198:215. doi: 10.1038/198215a0

Fosket, D. E., and Morejohn, L. C. (1992). Structural and functional organization of tubulin. Annu. Rev. Plant Physiol. Plant Mol. Biol. 43, 201-240. doi: 10.1146/ annurev.pp.43.060192.001221

Gould, S. B., Waller, R. F., and McFadden, G. I. (2008). Plastid evolution. Annu. Rev. Plant Biol. 59, 491-517. doi: 10.1146/annurev.arplant.59.032607.092915

Hori, T., Haraguchi, T., Hiraoka, Y., Kimura, H., and Fukagawa, T. (2003). Dynamic behavior of Nuf2-Hecl complex that localizes to the centrosome and centromere and is essential for mitotic progression in vertebrate cells. J. Cell Sci. 116, 3347-3362. doi: 10.1242/jcs.00645

Hu, Y.-J., and Zhou, Z.-G. (2001). Extraction of RAPD-friendly DNA from Laminaria japonica (Phaeophyta) after enzymatic dissociation of the frozen sporophyte tissues. J. Appl. Phycol. 13, 415-422. doi: 10.1023/a:1011920213639

Jakopec, V., Topolski, B., and Fleig, U. (2012). Sos7, an essential component of the conserved Schizosaccharomyces pombe Ndc80-MIND-Spc7 complex, identifies a new family of fungal kinetochore proteins. Mol. Biol. Cell 32, 3308-3320. doi: 10.1128/MCB.00212-12

Jensen, W. A. (1962). "Botanical histochemistry," in Principles and Practice, ed. W. A. Jensen (San Francisco, CA: W. H. Freeman and Company), 408.

Jiang, J., Birchler, J. A., Parrott, W. A., and Dawe, R. K. (2003). A molecular view of plant centromeres. Trends Plant Sci. 8, 570-575. doi: 10.1016/j.tplants.2003. 10.011

Joglekar, A., Bouck, D., Finley, K., Liu, X., Wan, Y., Berman, J., et al. (2008). Molecular architecture of the kinetochore-microtubule attachment site is conserved between point and regional centromeres. J. Cell Biol. 181, 587-594. doi: $10.1083 /$ jcb. 200803027

Keeling, P. J. (2010). The endosymbiotic origin, diversification and fate of plastids. Philos. Trans. R. Soc. B Biol. Sci. 365, 729-748. doi: 10.1098/rstb.2009.0103

Kerres, A., Vietmeier-Decker, C., Ortiz, J., Karig, I., Beuter, C., Hegemann, J., et al. (2004). The fission yeast kinetochore component Spc7 associates with the EB1 family member Mal3 and is required for kinetochore-spindle association. Mol. Biol. Cell 15, 5255-5267. doi: 10.1091/mbc.e04-06-0443

Laemmli, U. R. (1970). Cleavage of structural proteins during the assembly of the head of Bacteriophage T4. Nature 227, 680-685. doi: 10.1038/227680a0
Lewis, R. J. (1996). Chromosomes of the brown algae. Phycologia 35, 19-40. doi: 10.2216/i0031-8884-35-1-19.1

Liu, D., Ding, X., Du, J., Cai, X., Huang, Y., Ward, T., et al. (2007). Human NUF2 interacts with centromere-associated protein $\mathrm{E}$ and is essential for a stable spindle microtubule-kinetochore attachment. J. Biol. Chem. 282, 21415-21424. doi: 10.1074/jbc.M609026200

Liu, L., Yang, Q.-F., Dong, W.-S., Bi, Y.-H., and Zhou, Z.-G. (2017). Characterization and physical mapping of nuclear ribosomal RNA (rRNA) genes in the haploid gametophytes of Saccharina japonica (Phaeophyta). J. Appl. Phycol. 29, 2695-2706. doi: 10.1007/s10811-017-1206-3

Liu, Y., Bi, Y.-H., Gu, J.-G., and Zhou, Z.-G. (2012). Localization of a femalespecific marker on the chromosomes of the brown seaweed Saccharina japonica using fluorescence in situ hybridization. PLoS One 7:e48784. doi: 10.1371/ journal.pone.0048784

Maiato, H., DeLuca, J., Salmon, E. D., and Earnshaw, W. C. (2004). The dynamic kinetochore-microtubule interface. J. Cell Sci. 117, 5461-5477. doi: 10.1242/jcs. 01536

McDonnell, A. V., Jiang, T., Keating, A. E., and Berger, B. (2006). Paircoil2: improved prediction of coiled coils from sequence. Bioinformatics 22, 356-358. doi: 10.1093/bioinformatics/bti797

Morejohn, L. C., and Fosket, D. E. (1991). The biochemistry of compounds with anti-microtubule activity in plant cells. Pharm. Ther. 51, 217-230. doi: 10.1016/ 0163-7258(91)90078-Z

Nabetani, A., Koujin, T., Tsutsumi, C., Haraguchi, T., and Hiraoka, Y. (2001). A conserved protein, Nuf2, is implicated in connecting the centromere to the spindle during chromosome segregation: a link between the kinetochore function and the spindle checkpoint. Chromosoma 110, 322-334. doi: 10.1007/ s004120100153

Nourani, A., Robert, F., and Winston, F. (2006). Evidence that Spt2/Sin1, an HMGlike factor, plays roles in transcription elongation, chromatin structure, and genome stability in Saccharomyces cerevisiae. Mol. Cell. Biol. 26, 1496-1509. doi: 10.1128/MCB.26.4.1496-1509.2006

Oliveira, L. C., and Torres, G. A. (2018). Plant centromeres: genetics, epigenetics and evolution. Mol. Biol. Rep. 45, 1491-1497. doi: 10.1007/s11033-018-4284-7

Olmsted, J. B. (1981). Affinity purification of antibodies from diazotized paper blots of heterogeneous protein samples. J. Biol. Chem. 256, 11955-11957. doi: 10.1093/emboj/cdg261

Osborne, M. A., Schlenstedt, G., Jinks, T., and Silver, P. A. (1994). Nuf2, a spindle pole body-associated protein required for nuclear division in yeast. J. Cell Biol. 125, 853-866. doi: $10.1083 /$ jcb.125.4.853

Przewloka, M. R., and Glover, D. M. (2009). The kinetochore and the centromere: a working long distance relationship. Annu. Rev. Genet. 43, 439-465. doi: 10. 1146/annurev-genet-102108-134310

Ramahi, S. J. (2012). Quantitative Analysis of CENH3 and NDC80 Complexes in Arabidopsis Kinetochores During Mitosis and Meiosis. Ph.D. thesis, University of California, Berkeley, CA.

Richards, E. I., and Dawet, R. K. (1998). Plant centromeres: structure and control. Curr. Opin. Plant Biol. 1, 130-135. doi: 10.1016/S1369-5266(98)80014-9

Ritter, K. (1991). Affinity purification of antibodies from sera using polyvinylidenedifluoride (PVDF) membranes as coupling matrices for antigens presented by autoantibodies to triosephosphate isomerase. J. Immunol. Methods 137, 209-215. doi: 10.1016/0022-1759(91)90026-C

Santaguida, S., and Musacchio, A. (2009). The life and miracles of kinetochores. EMBO J. 28, 2511-2531. doi: 10.1038/emboj.2009.173

Schubert, V., Lermontova, I., and Schubert, I. (2013). The Arabidopsis CAP-D proteins are required for correct chromatin organisation, growth and fertility. Chromosoma 122, 517-533. doi: 10.1007/s00412-013-0424-y

Shin, J., Jeong, G., Park, J.-Y., Kim, H., and Lee, I. (2018). MUN (MERISTEM UNSTRUCTURED), encoding a SPC24 homolog of NDC80 kinetochore complex, affects development through cell division in Arabidopsis thaliana. Plant J. 93, 977-991. doi: 10.1111/tpj.13823

Starr, R. C., and Zeikus, J. A. (1993). UTEX-The culture collection of algae at the University of Texas at Austin 1993 list of cultures. J. Phycol. 29(Suppl. 2), 1-106. doi: 10.1111/j.0022-3646.1993.00001.x

Sundin, L. J. R., Guimaraes, G. J., and DeLuca, J. G. (2011). The NDC80 complex proteins Nuf2 and $\mathrm{Hecl}$ make distinct contributions to kinetochore(microtubule attachment in mitosis. Mol. Biol. Cell 22, 759-768. doi: $10.1091 / \mathrm{mbc} . \mathrm{E} 10-08-0671$ 
Suzuki, T., Ide, N., and Tanaka, I. (1997). Immunocytochemical visualization of the centromeres during male and female meiosis in Lilium longiflorum. Chromosoma 106, 435-445. doi: 10.1007/s004120050265

Takasu, H., Jee, J. G., Ohno, A., Goda, N., Fujiwara, K., Tochio, H., et al. (2005). Structural characterization of the MIT domain from human Vps4b. Biochem. Biophys. Res. Commun. 334, 460-465. doi: 10.1016/j.bbrc.2005. 06.110

Tamura, K., Stecher, G., Peterson, D., Filipski, A., and Kumar, S. (2013). MEGA6: molecular evolutionary genetics analysis version 6.0. Mol. Biol. Evol. 30, 2725 2729. doi: 10.1093/molbev/mst197

Wei, R. R., Sorger, P. K., and Harrison, S. C. (2005). Molecular organization of the Ndc80 complex, an essential kinetochore component. Proc. Natl. Acad. Sci. U.S.A. 102, 5363-5367. doi: 10.1073/pnas.0501168102

Westermann, S., Drubin, D. G., and Barnes, G. (2007). Structures and functions of yeast kinetochore complexes. Annu. Rev. Biochem. 76, 563-591. doi: 10.1146/ annurev.biochem.76.052705.160607

Wigge, P. A., and Kilmartin, J. V. (2001). The Ndc80p complex from Saccharomyces cerevisiae contains conserved centromere components and has a function in chromosome segregation. J. Cell Biol. 152, 349-360. doi: 10.1083/jcb.152.2.349

Yabu, H., and Yasui, H. (1991). Chromosome number in four species of Laminaria (Phaeophyta). Jpn. J. Phycol. 39, 185-187.

Yang, Q.-F., Liu, L., Bi, Y.-H., and Zhou, Z.-G. (2017). Telomeric localization of the Arabidopsis-type heptamer repeat, (TTTAGGG)n, at the chromosome ends in Saccharina japonica (Phaeophyta). J. Phycol. 53, 235-240. doi: 10.1111/jpy. 12497

Ye, N., Zhang, X., Miao, M., Fan, X., Zheng, Y., Xu, D., et al. (2015). Saccharina genomes provide novel insight into kelp biology. Nat. Commun. 6:6986. doi: 10.1038/ncomms7986

Ye, R.-X., Yu, Z., Shi, W.-W., Gao, H.-J., Bi, Y.-H., and Zhou, Z.-G. (2014). Characterization of $\alpha$-type carbonic anhydrase (CA) gene and subcellular localization of $\alpha$-CA in the gametophytes of Saccharina japonica. J. Appl. Phycol. 26, 881-890. doi: 10.1007/s10811-013-0221-2

Zhou, Z.-G., and Wu, C.-Y. (1998). Clone culture of Laminaria japonica and induction of its sporophytes. Chin. J. Biotechnol. 14, 109-111. doi: 10.13345/j. cjb.1998.01.020

Conflict of Interest: The authors declare that the research was conducted in the absence of any commercial or financial relationships that could be construed as a potential conflict of interest.

Copyright (C) 2020 Dong, Liu, Liu, Du, Bi and Zhou. This is an open-access article distributed under the terms of the Creative Commons Attribution License (CC BY). The use, distribution or reproduction in other forums is permitted, provided the original author(s) and the copyright owner(s) are credited and that the original publication in this journal is cited, in accordance with accepted academic practice. No use, distribution or reproduction is permitted which does not comply with these terms. 